\section{Peripheral Ameloblastoma with Dystrophic Calcification: An Unusual Feature in Non- Calcifying Odontogenic Tumors}

Nelise Alexandre da Silva Lascane ${ }^{1}$, Bruno Tavares Sedassari ${ }^{1}$, Fábio de Abreu Alves², Marina Helena Cury Gallottini', Suzana Cantanhede Orsini Machado de Sousa ${ }^{1}$

\author{
'Department of Oral Pathology, \\ Dental School, University of São \\ Paulo, São Paulo, SP, Brazil \\ ${ }^{2}$ Department of Oral Diagnosis, \\ Dental School, University of São \\ Paulo, São Paulo, SP, Brazil \\ Correspondence: Nelise Alexandre \\ da Silva Lascane, Avenida Prof. \\ Lineu Prestes 2227, 05508-000 \\ São Paulo, SP, Brasil. Tel: +55-11- \\ 3091-7912. e-mail: nelise@usp.br
}

KeyWords: peripheral ameloblastoma odontogenic tumor, dystrophic calcification

\section{Introduction}

Ameloblastoma is a benign odontogenic tumor that presents various histologic growth patterns. The most common microscopic patterns are follicular and plexiform, followed by acanthomatous. This pattern is characterized by extensive metaplasia that is often associated with keratinization in the central portion of the epithelial islands. These islands tend to be arranged in an outer layer of columnar cells with nuclear palisading which resemble ameloblasts. The nuclei of these columnar cells are centrally polarized, oriented away from the peripheral basement membrane, and surround a central area in which neoplastic cells make a loose aspect resembling the stellate reticulum of the enamel organ $(1,2)$.

Excluding odontomas, which are considered as hamartomatous odontogenic lesions, ameloblastoma is the most common odontogenic tumor, and its peripheral counterpart is very rare, representing about 1.3 to $10 \%$ of all ameloblastomas. In contrast to the aggressive behavior of central ameloblastomas, extraosseous lesions are typically nodular masses with a smooth, granular, pebbly, warty or papillary surface and, by definition, have no clinical, surgical or radiological evidence of infiltration in the underlying bone; if there is bone involvement beyond the cortical plate, the lesion should be classified as intraosseous ameloblastoma $(2,3)$.

The purpose of this paper is to report the clinical, radiological and histopathological aspects of an extremely rare case of a mandibular peripheral acanthomatous ameloblastoma showing dystrophic calcification in an adult male patient.

\section{Case Report}

A 56-year-old male patient was referred to the Oral Diagnosis Clinic of the School of Dentistry, University of São Paulo, Brazil, to evaluate a painless lesion with 10-month duration in the vestibular gingival region between the mandibular left incisors. On intraoral examination, a 1.5 $\mathrm{cm}$-diameter nodule with a smooth surface was observed (Fig. 1A). A radiographic exam (Fig. 1B) and computed tomography exams (Fig. 1C) showed only superficial erosion of the underlying bone crest. The clinical diagnosis was peripheral ossifying fibroma. An excisional biopsy was performed under local anesthesia, and the tissue was submitted to histopathological examination.

Histological examination of the material showed a mucosal fragment exhibiting an odontogenic neoplasm. The neoplasm was characterized by the presence of epithelial islets delimited by a single layer of tall columnar ameloblast-like cells with hyperchromatic nuclei, which were disposed in a palisade fashion and presented reversed polarity. These cells were dispersed throughout the lamina propria, extending to the submucosa and surrounded a core of loosely arranged angular cells resembling the stellate reticulum of the enamel organ. Extensive squamous metaplasia, often associated with keratinization, and several basophilic areas compatible with dystrophic calcification were evident within the islands. The surface orthokeratinized stratified squamous epithelium that coated the oral mucosa was intact (Fig. 2A-C).

Based on clinical, imaging and histological features, a diagnosis of peripheral acanthomatous ameloblastoma with areas of dystrophic calcification was established. The patient 
was submitted to a complementary surgical procedure with extended excision on the border of the former lesion. The patient is presently asymptomatic and without evidence of local recurrence after a year of treatment.

\section{Discussion}

One of the unique features regarding the pathology of the jaws is the occurrence of odontogenic tumors. Odontogenic tumors comprise a group of uncommon lesions that share the common aspect of arising from the teeth-forming tissues, either the epithelial component, the ectomesenchymal component, or both. Their clinical behavior varies from harmless non-neoplastic hamartomas to frankly aggressive tumors, such as central ameloblastoma. Peripheral ameloblastoma is a rare variant of benign odontogenic tumor that exhibits the histologic characteristics of its intraosseous counterpart but occurs in the soft tissues without bone involvement, except for superficial erosion or depression of the bone crest, as observed in the present case $(1,4)$.

Despite its rarity, peripheral ameloblastoma is the second most frequent peripheral odontogenic tumor, accounting for $28.9 \%$ of cases, preceded by odontogenic fibroma (5).

Similar to other peripheral odontogenic tumors,
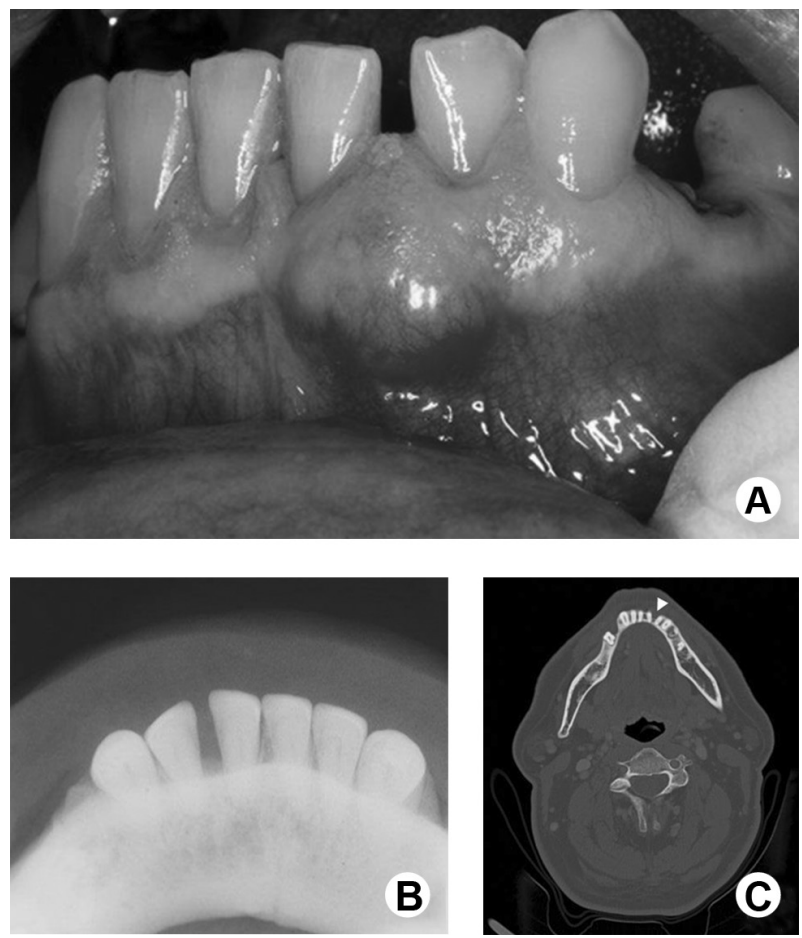

Figure 1. A: Nodule on the vestibular region between the mandibular left incisors. B: Occlusal radiograph showing absence of central involvement. C: CT scan showing vestibular erosion between the mandibular left incisors (axial slice) (arrow head). peripheral ameloblastomas are believed to be derived from remnants of the dental lamina or from basal cells of the oral surface epithelium $(6,7)$. In a cytogenetic study of a case of peripheral ameloblastoma found trisomy 7 as the only genetic alteration, differently from the intraosseous counterpart of ameloblastoma in which loss of chromossome 22 has been described, suggesting that tumorigenesis of these lesions is different $(8,9)$. The peripheral ameloblastoma tends to occur in the mandible, and the lingual gingiva is its most frequent site, followed by the anterior area whereas in the maxilla, soft palatal tissue of the tuberosity area is most affected $(1,2,10)$. There are reports of extragingival peripheral ameloblastomas - buccal mucosa and floor of the mouth - but those are supposed to be a basal cell adenoma or an ameloblastoid variant of a misdiagnosed squamous cell carcinoma that resemble ameloblastoma $(1,11,12)$.

Additionally, males are more affected than females, at a ratio of 1.9:1, and frequently occur between the fifth and the seventh decades of life, which is older than for central ameloblastomas (2). The reported case showed the most commonly observed clinical characteristics in peripheral ameloblastomas: a male patient in the fifth decade of life presenting a nodule in the anterior mandible gingiva.

Clinically, the differential diagnosis of peripheral ameloblastomas should mainly include any peripheral hyperplastic swelling superficial to the alveolar ridge, such as peripheral hyperplastic fibroma, pyogenic or peripheral giant-cell granuloma and fibroma $(1,6)$. It is extremely important to perform a detailed imaging study of peripheral ameloblastomas to exclude bone involvement
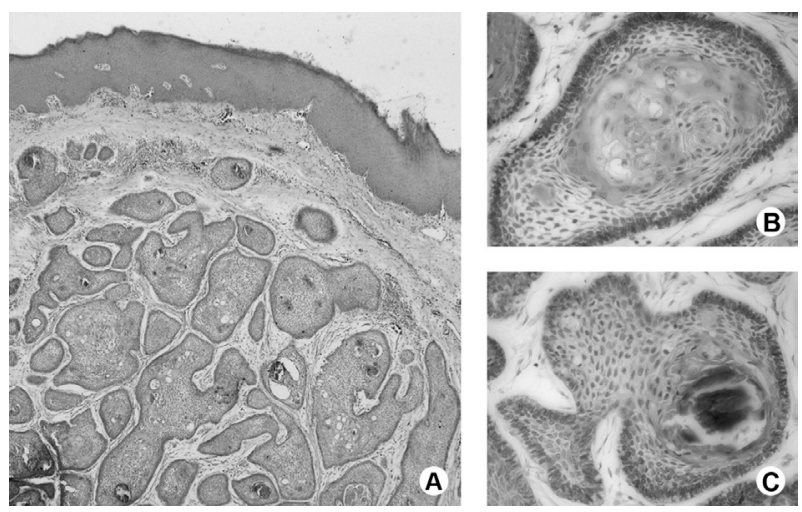

Figure 2. A: Mucosal fragment showing multiple islands of odontogenic epithelium exhibiting peripheral columnar cells arranged in a palisade fashion with hyperchromatic nuclei. Within the islands, squamous metaplasia, keratinization and dystrophic calcification are observed (HE; Original magnification 25x). B: A higher power view of an island showing squamous metaplasia and keratinization (HE; Original magnification $400 \times)$. C: An island showing a core of loosely arranged angular cells with squamous metaplasia and dystrophic calcification (HE; Original magnification $400 \times$ ). 
by the tumor mass, which could culminate in misdiagnosis, recurrences and modification of the patient prognosis. In the imaging exams, this patient exhibited a mild thinning of the mandibular cortical bone, which could be explained by the compression exerted by the neoplastic process, which can stimulate resorption of the underlying bone tissue. The cortical bone represents an efficient barrier to the invasion of the jawbone by the peripheral tumor, leading some authors to question about the biological behavior: whether it is a hamartoma or persistent hyperplasia rather than a neoplasia $(1,13)$.

The histological differential diagnosis includes peripheral odontogenic fibroma, odontogenic gingival epithelial hamartoma, peripheral squamous odontogenic tumor and intraoral basal cell carcinoma $(2,14)$. Given the frequent areas of squamous metaplasia in the neoplastic islands, the main microscopic differential diagnosis in the present case was a squamous odontogenic tumor. However, the ameloblastic features helped concluding the diagnosis. In squamous odontogenic tumors, the epithelial islands are usually lined by flat or cuboidal basal cells and often exhibit vacuolization and microcyst formation. Additionally, some islands may present calcified material (2).

Like in central ameloblastomas, the peripheral counterpart exhibits the same histopathological subtypes. The follicular and acanthomatous patterns are the most common findings in peripheral ameloblastoma $(1,10)$. Calcifications, dentinoid, bone-like or cementum-like material are considered rare histopathological features (1).

Dystrophic calcifications, which are not usually present in ameloblastomas, were the most striking feature of this case. The presence of calcifications has been described in several cases of ameloblastomas of the acanthomatous type (13,15-17), although the occurrence of calcifications is not characteristic of peripheral ameloblastomas (1). Some studies have suggested that dystrophic calcification in peripheral ameloblastomas might be a sign of a potentially malignant feature $(13,17)$, which is supported by its occurrence in cases of ameloblastic carcinoma $(18,19)$. Occasionally, calcification may be a consequence of an intense apoptotic activity, and the terminal differentiation of keratinocytes is considered to be a variant of the apoptotic process $(20,21)$. As the present case did not show any signs of malignancy, the latter supposition is more likely to be the cause of the calcifications.

Several studies have demonstrated that peripheral ameloblastomas may present indolent behavior compared with the central variant $(10,22,23)$. Thus, the treatment of choice is a conservative supraperiosteal excision with adequate disease-free margins $(1,4)$. Tumor recurrence is uncommon and, although very rare, some peripheral ameloblastomas were reported to undergo malignant transformation into ameloblastic carcinoma $(24,25)$. In the present case, the treatment consisted of surgical resection of the tumor.

In summary, peripheral ameloblastomas, especially those of the acanthomatous histological subtype and with areas of dystrophic calcification are rare tumors. Imaging exams are extremely important to differentiate true peripheral lesions from lesions that destroy the bone and invade adjacent tissues. We suggest a long-term follow-up in peripheral ameloblastomas cases.

\section{Resumo}

Ameloblastoma periférico é a contraparte rara extraóssea do ameloblastoma central, que ocorre em tecidos moles e pode causar reabsorção da crista óssea. Este estudo reporta um ameloblastoma periférico localizado na gengiva vestibular de um homem de 56 anos de idade, que apresentava extensas áreas de metaplasia escamosa, queratinização e calcificação distrófica dentro das ilhas neoplásicas. É enfatizada a necessidade de um estudo de imagem detalhado e acompanhamento prolongado para excluir envolvimento ósseo sempre que o diagnóstico de ameloblastoma periférico for considerado.

\section{References}

1. Philipsen HP, Reichart PA, Nikai H, Takata T, Kudo Y. Peripheral ameloblastoma: biological profile based on 160 cases from the literature. Oral Oncol 2001;37:17-27.

2. Gardner D, Heikinheimo $K$, Shear $M$, Philipsen $H$, Coleman $H$. Ameloblastoma. In: Barnes L, Eveson J, Reichart P, Sidransky D, editors. World Health Organization - Classification of Tumours Head and Neck Tumours Pathology \& Genetics. Lyon: IARC Press; 2005. p. 296-300.

3. Nonaka CF, de Oliveira PT, de Medeiros AM, de Souza LB, Freitas ReA. Peripheral ameloblastoma in the maxillary gingiva: a case report. N Y State Dent J 2013;79:37-40.

4. Reichart PA, Philipsen HP, Sonner S. Ameloblastoma: biological profile of 3677 cases. Eur J Cancer B Oral Oncol 1995;31B:86-99.

5. Buchner A, Merrell PW, Carpenter WM. Relative frequency of peripheral odontogenic tumors: a study of 45 new cases and comparison with studies from the literature. J Oral Pathol Med 2006;35:385-391.

6. Martelli-Júnior H, Souza LN, Santos LA, Melo-Filho MR, De Paula AM. Peripheral ameloblastoma: a case report. Oral Surg Oral Med Oral Pathol Oral Radiol Endod 2005;99:E31-33.

7. Bertossi D, Favero V, Albanese M, De-Santis D, Martano M, Padovanodi-Leva A, et al.. Peripheral ameloblastoma of the upper gingiva: Report of a case and literature review. J Clin Exp Dent 2014;6:e180-184.

8. Manor E, Delgado B, Joshua BZ, Brennan PA, Bodner L. Trisomy 7 as sole aberration in peripheral ameloblastoma of the mandible. $J$ Oral Maxillofac Surg 2013;71:1217-1219.

9. Toida $M$, Balázs $M$, Treszl $A$, Rákosy $Z$, Kato $K$, Yamazaki $Y$, et al.. Analysis of ameloblastomas by comparative genomic hybridization and fluorescence in situ hybridization. Cancer Genet Cytogenet 2005;159:99-104.

10. Kishino $M$, Murakami S, Yuki M, lida S, Ogawa $Y$, Kogo $M$, et al.. A immunohistochemical study of the peripheral ameloblastoma. Oral Dis 2007:13:575-580.

11. Yamanishi T, Ando S, Aikawa T, Kishino M, Nakano Y, Sasai K, et al.. A case of extragingival peripheral ameloblastoma in the buccal mucosa. J Oral Pathol Med 2007;36:184-186.

12. Yuwanati MB, Singh $A$, Gadbail AR, Mhaske S. Hybrid peripheral ameloblastoma of cheek mucosa. BMJ Case Rep 2013; doi: 10.1136/ bcr-2013-009510.

13. Redman RS, Keegan BP, Spector CJ, Patterson RH. Peripheral ameloblastoma with unusual mitotic activity and conflicting evidence 
regarding histogenesis. J Oral Maxillofac Surg 1994;52:192-197.

14. Woods TR, Cohen DM, Islam MN, Kratochvil FJ, Stewart JC, Reeder SL, et al.. Intraoral basal cell carcinoma, a rare neoplasm: report of three new cases with literature review. Head Neck Pathol 2014;8:339-348.

15. Gardner DG. Peripheral ameloblastoma: a study of 21 cases, including 5 reported as basal cell carcinoma of the gingiva. Cancer 1977;39:16251633.

16. $\mathrm{Ng} \mathrm{KH}$, Siar CH. Peripheral ameloblastoma with clear cell differentiation. Oral Surg Oral Med Oral Pathol 1990;70:210-213.

17. Tajima Y, Kuroda-Kawasaki M, Ohno J, Yi J, Kusama K, Tanaka H, et al.. Peripheral ameloblastoma with potentially malignant features: report of a case with special regard to its keratin profile. J Oral Pathol Med 2001;30:494-498.

18. Corio RL, Goldblatt LI, Edwards PA, Hartman KS. Ameloblastic carcinoma: a clinicopathologic study and assessment of eight cases. Oral Surg Oral Med Oral Pathol 1987;64:570-576.

19. Naik V, Kale AD. Ameloblastic carcinoma: a case report. Quintessence Int 2007;38:873-879.

20. Kim KM. Apoptosis and calcification. Scanning Microsc 1995;9:11371175; discussion 1175-1178.

21. Maruoka $Y$, Harada $H$, Mitsuyasu $T$, Seta $Y$, Kurokawa $H$, Kajiyama $M$, et al.. Keratinocytes become terminally differentiated in a process involving programmed cell death. Biochem Biophys Res Commun 1997;238:886-890

22. Bologna-Molina R, Mosqueda-Taylor A, Lopez-Corella E, Almeida OP, Carrasco-Daza D, Garcia-Vazquez F, et al.. Syndecan-1 (CD138) and $\mathrm{Ki}-67$ expression in different subtypes of ameloblastomas. Oral Oncol 2008;44:805-811.

23. Bologna-Molina R, Mosqueda-Taylor A, Lopez-Corella E, de Almeida OP, Carrasco-Daza D, Farfán-Morales JE, et al.. Comparative expression of syndecan-1 and $\mathrm{Ki}-67$ in peripheral and desmoplastic ameloblastomas and ameloblastic carcinoma. Pathol Int 2009;59:229-233.

24. McClatchey KD, Sullivan MJ, Paugh DR. Peripheral ameloblastic carcinoma: a case report of a rare neoplasm. J Otolaryngol 1989;18:109-111.

25. Califano L, Maremonti P, Boscaino A, De Rosa G, Giardino C. Peripheral ameloblastoma: report of a case with malignant aspect. Br J Oral Maxillofac Surg 1996;34:240-242.

Received March 19, 2014 Accepted June 9, 2014 